\title{
Zika Virus and Microcephaly: An Enemy of Public Health
}

\author{
Antonio Marlos Duarte de \\ Melo $^{1}$; \\ Ana Beatriz Callou Sampaio \\ Neves ${ }^{1}$; \\ Gabriel Pereira Bernardo ${ }^{1}$; \\ Ruth Figueiredo de Araujo ${ }^{\prime}$; \\ Lorena Pereira Bernardo ${ }^{1}$; \\ Lucas Leimig Telles Parente', \\ Rodrigo Emmanuel Leimig \\ Telles Parente'; \\ Maria Valéria Leimig Telles ${ }^{2}$
}

\begin{abstract}
The reality of the Brazilian public health at a time of financial crisis gets even worse the situation of the Zika virus outbreak, which has expressed concern about its relationship with the cases of microcephaly that currently plague the country. This relationship seems to be increasingly close. The Zika virus, currently has been a major enemy of international public health, increasing astronomically cases of microcephaly in Brazil and other equally worrying disorders. This virus is transmitted by the Aedes aegypti.
\end{abstract}

Keywords: Zika, microcephaly, public health.

\section{Introduction}

The Zika virus (ZIVK) is an enveloped virus with single stranded RNA of the genus Flavivirus. It is an arbovirus transmitted by the mosquito Aedes. The virus was first detected in a monkey in 1947 in Uganda and its first appearance in humans was in 1952 in Uganda and Tanzania (Dick; Kitchen; Haddow, 1952; Duffy et al., 2009). The first outbreaks of ZIKV infection were reported in 2007 by Micronesia, followed by other outbreaks in French Polynesia, Pacific Islands and northern Brazil (Duffy et al., 2009; World Health Organization, 2016). The virus has two lines: African and Asian. The virus of the American continent originated from the Asian lineage (Haddow et al., 2016; Ozkurt; Tanriverdi, 2017).

\footnotetext{
${ }^{1}$ Academics of Medicine at the Faculty of Medicine Estácio de Juazeiro do Norte - FMJ. Juazeiro do Norte, Ceará, Brazil. Contacts: marlos_duarte@outlook.com; beatriz_callousampaio@ hotmail.com; gabrielpbernardo@hotmail.com; $\quad$ ruthfigueiredoaraujo@gmail.com; $\quad$ lorenapbernardo@hotmail.com; parente_lucas@ hotmail.com; rodrigo.parente.leimig@ hotmail.com;

${ }^{2}$ Graduation in Medicine by the Foundation of Higher Education of Pernambuco - FESP. Medical Residency in Pediatrics - Instituto de Medicina Integral Professor Fernando Figueira - IMIP. Specialization in Pediatrics Integral Medicine Institute Professor Fernando Figueira - IMIP. Master's Degree in Child and Adolescent Health - State University of Ceará - UECE. PhD in Neurosciences - Federal University of São Paulo - UNIFESP. Pediatric Physician of Hospital São Lucas. Professor at the Faculty of Medicine Estácio de Juazeiro do Norte FMJ. Juazeiro do Norte, Ceará, Brazil. Contact: valerialeimigtelles@ hotmail.com
} 
The main route of transmission of the virus to humans is the Aedes aegypti mosquito. The ZIKV was isolated from blood, urine, saliva and semen humans, can thus be transmitted via the placenta, perinatal, sexual and through blood (Bonaldo et al, 2016;. Davidson et al, 2016;. Frank et al , Et al., 2014). In addition, the virus can resist up to 115 days in vaginal secretions and semen (Ozkurt; Tanriverdi, 2017; Sharma; Lal, 2017).

Similar to other flaviviruses, ZIKV enters endocytosis in dendritic cells, remaining in the nuclei of the same if replicating and spreading in the blood. The infection is self-limiting (Ozkurt; Tanriverdi, 2017; Sharma; Lal, 2017).

Studies in Brazil have recently provided increasing evidence of the association between Zika in pregnant women and the development of severe neural developmental disorders such as microcephaly in fetuses and newborns (Driggers et al., 2016). Infants with microcephaly may develop hearing loss, motor skills defects, intellectual impairment, developmental delay, and vision problems (Nunes et al., 2016; Garza-Gonzalez et al., 2017).

The virus reaches the fetus through the transplacental pathway, being observed in the cerebral tissue of the same (Calvet et al., 2016; Martines et al., 2016). ZIKV is more teratogenic in the first trimester, when microcephaly develops. Zika virus IgM antibodies were detected in the cerebrospinal fluid of a microcephalic baby as evidence that ZIKV was the causative agent of microcephaly (Cordeiro et al., 2016; Ozkurt; Tanriverdi, 2017; Meneses et al., 2017).

\section{Discussion}

The Zika virus is a flavivirus that has been a major enemy of international public health at the present juncture, since on November 30, 2016 the autochthonous vector transmission of the ZIKV has been documented in 75 countries and territories since 2007 and 49 countries And territories had their first reports in 2015 (Alvino, Mello, Oliveira, 2016, Boeuf et al., 2016, Brazil, 2017). In addition, ZIKV is likely to increase astronomically the cases of microcephaly in Brazil and other disturbances of similar concern (Alvino; Mello; Oliveira, 2016; Boeuf et al., 2016; Neta et al., 2016; Oliveira et al., 2016). The World Health 
Organization (WHO) issued a global alert for this topic, intensifying the need for discussion in academic research centers. In order to understand this relationship between ZIKV and microcephaly, it should be noted that epidemiological data suggest that microcephaly cases in Brazil may be associated with the introduction of ZIKV (Calvin et al., 2016; Oliveira et al., 2016) . It is important to pay attention to this explosion of episodes can still foster a concern for international travel to 62 countries with such a problem, according to the Centers for Disease Control and Prevention (CDC), for pregnant women could consider deferring travel to affected areas (Samarasekera; Triunfol, 2016).

Evidence shows that this relationship is possible because pregnant women - with fetuses with proven microcephaly - had clinical manifestations that could have been symptoms of ZIKV infection, including fever, myalgia, and rash (Calvet et al., 2016). On 1 February 2016, the active transmission of ZIKV was being reported in 28 countries, primarily in the Americas, including Brazil, Mexico, Colombia, Haiti, Venezuela and Barbados (Samarasekera; Triunfol, 2016; The lancet, 2016).

At the beginning of the alarm, in October 2015, the Brazilian Federal Ministry of Health reported an explosion of new cases of microcephaly, especially in the state of Pernambuco, located in Northeast Brazil (Ayres, 2016, Samarasekera, Triunfol, 2016) . To date, approximately 400,000 cases of ZIKV disease have been reported in 24 states in Brazil, but this number may be significantly higher (Ayres, 2016; Yakob; Walker, 2016). Thus, studies have begun to show that there is a relationship between ZIKV and that eruption of new cases of microcephaly, since tests for the dengue virus, chikungunya fever, rubella, cytomegalovirus - another important cause of microcephaly in pregnant women -, Toxoplasma Gondii, parvovirus B19 were all negative (Calvet et al., 2016; Rasmussen et al., 2016). To show how this is worrying, between November 2015 and the third week of January 2016, 4,180 new cases of microcephaly have occurred (Samarasekera; Triunfol, 2016). On December 3, 2016, there were 10,441 cases of microcephaly, of which 7,268 were investigated, and 2,228 cases suggest the association of congenital infections with these cases of microcephaly (Brasil, 2017; Neta et al., 2016). In addition to these concerns, the disease is transmitted by the vector, but sexual transmission - including few percentages of transmission by oral and anal sex - and congenital cases have been reported (Ayres, 2016; Boeuf et al., 2016; Deckard et al., 2016 ; Fréour et al, 2016). No less decisive, the virus can cross the placental barrier and that would explain the question of how the virus reaches the fetus and its 
affinity for nervous tissue and also show why women have tested negative for other diseases transmitted by the same vector: serum tests, and urine samples of amniotic fluid, using the anti-virus dengue $\operatorname{IgM}$, anti-dengue-virus $\operatorname{IgG}$ anti-chikungunya-virus $\operatorname{IgM}$ and antichikungunya-virus IgG were negative using ELISA (Calvet et al., 2016 ).

Brault et al. (2016) found that ZIKV is tropism by neural stem cells, impairing cell cycle progression and inhibiting apoptosis in the early stages of infection. Mcgrath et al. (2017) have shown that the virus can impair neuronal differentiation. Recently, Smith et al. (2017) showed that ZIKV causes acute and subacute encephalitis / encephalomyelitis, neuronal cell death and astrogliosis. In their experimental study, Cugola et al. (2016) reported that ZIKV causes congenital defects. They showed that after the virus crossing the placenta, it infects cortical cells and causes cell death and affect neurological development. In a recent study, Vermillion et al. (2017) investigated the pathogenesis of intrauterine ZIKV in a rat model. They found the viral antigen on placental trophoblast and endothelial cells and on fetal brain endothelial, glial and neural progenitor cells. They showed ZIKV capacity to infect fetal and placental tissues and fetal viability by reducing inflammation and placental dysfunction. The most frequent clinical symptoms in infants with ZIKV infection are irritability, convulsion, cloning, crying, pyramidal and extrapyramidal symptoms, epilepsy, dysphagia and persistent primitive reflex (Moura da silva et al., 2016). The findings of positive tests were reported as a low head growth, biparietal depression, prominent occipital, excess nuchal skin, arthrogryposis, cleft lip or cleft palate (Moura da silva et al., 2016). Microcephaly may be present or develop within 5 months after birth in children with congenital ZIKV infection (Friedrich, 2017). Oliveira et al. (2016) reported that febrile illness with rash in the first trimester was associated with microcephaly. France et al. (2016) found that the presence of rash in the third trimester of pregnancy was associated with fetal brain abnormalities, despite normal head size. Congenital abnormalities were reported in 5\% of pregnancies of 972 infants completed in 1297 pregnancies ZIKV infection.

The anomaly rate was similar in infants of symptomatic and asymptomatic pregnancies. The proportion of congenital anomaly was $15 \%$ in infants whose exposure to the virus occurred during the first trimester. Microcephaly was found in $75 \%$ of infants with brain abnormalities of mothers with ZIKV-confirmed infection (Reynolds et al., 2017). One way to diagnose cases of microcephaly is through imaging, which has as its main objective the detection of neurological complications related to transplacental infection by ZIKV, such as 
microcephaly, cerebral calcifications, neuronal migration disorders, loss of brain tissue and Dilation of the ventricular system. The extent and severity of intracranial changes are directly related to the gestational period in which the fetus was infected by the virus, are more severe and extensive during the first trimester of gestation and milder in the third trimester. The imaging evaluation of the fetus or the newborn has been indicated in cases of confirmed or inconclusive maternal infection by ZIKV, as well as by laboratory tests or compatible clinical findings (Nunes et al., 2016).

To try to resolve this public health problem, the Brazilian Ministry of Health has stated that it is interested in developing a vaccine to prevent infections by ZIKV, but studies may take up to five years to complete the final tests to develop the vaccine (Samarasekera; Triunfol, 2016; Yakob; Walker, 2016). Until then, the main concern will be with the vector, because even that is still a dim light: the transmission of urban ZIKV may involve other species of mosquitoes due to the virus's ability to adapt (Ayres, 2016). But this comes at a dangerous time for Brazil, as the country's economy is shrinking, while unemployment and inflation are rising, threatening the already fragile health system (Horton, 2016). Other countries such as Jamaica, Colombia, El Salvador, perplexed by this infection and its public health consequences, have advised women to postpone pregnancy (Samarasekera, Triunfol, 2016, Yakob, Walker, 2016). The virus will provide an opportunity to advance the fight for public health in these countries (Horton, 2016).

In addition to microcephaly, other serious neurological complications such as Guillain-Barré syndrome have been reported in patients infected with ZIKV, making the subject more relevant (Boeuf et al., 2016; Calvet et al., 2016; Cao-lormeau et al., 2016, Saadroy, Van den Driessche, Ma, 2016). To solve this epidemic more easily, the population can take some care: using repellents, long and clear clothes; Avoiding the formation of foci where vector larvae develop (Samarasekera; Triunfol, 2016).

\section{Conclusion}

The number of deaths by ZIKV is reduced and the number of hospitalizations is small but the problems for public health are serious and can cause a large increase in resources in health to properly watch all this new population with microcephaly. 


\section{References}

Alvino, A. C. M. I., Mello, L. R. M., Oliveira J. A. M. M. (2016). Association of arthrogryposis in neonates with microcephaly due to Zika virus - a case serie. Rev. Bras. Saúde Matern. Infant, v. 16, s. 1, p. 83-8, Nov.

Ayres, C. F. (2016). Identification of Zika virus vectors and implications for control. Lancet Infect Dis, v. 16, n. 3, p. 278-9, Mar.

Boeuf, P., et al. (2016). The global threat of Zika virus to pregnancy: epidemiology, clinical perspectives, mechanisms, and impact. BMC Medicine, v. 14, n. 112: p. 1-9, Ago.

Bonaldo, M. C., et al. (2016). Isolation of infective Zika virus from urine and saliva of patients in Brazil. PLoS Negl Trop Dis, v. 10, n. 6, e0004816, Jun.

Brasil. (2017). Informe Epidemiológico No 55. [Online]. Disponível em: <http://combateaedes.saude.gov.br/images/pdf/informe_microcefalia_epidemiologico55.pdf $>$. Acesso em: 20 jul.

Brault, J. B., et al. (2016). Comparative analysis between flaviviruses reveals specific neural stem cell tropism for zika virus in the mouse developing neocortex. EBioMedicine, v. 10, p. 71-6, Ago.

Calvet, G., et al. (2016). Detection and sequencing of Zika virus from amniotic fluid of fetuses with microcephaly in Brazil: a case study. Lancet Infect Dis, v. 16, n. 6, p. 653-60.

Cao-Lormeau, V. M., et al. (2016). Guillain-Barré syndrome outbreak associated with Zika virus infection in French Polynesia: a case-control study. The Lancet, v. 387, n. 10027, p. $1531-9$.

Cordeiro, M. T., et al. (2016). Results of a Zika Virus (ZIKV) Immunoglobulin M-specific diagnostic assay are highly correlated with detection of neutralizing anti-ZIKV antibodies in neonates with congenital disease. J Infect Dis, v. 214, p. 1897-1904, Dez.

Cugola, F. R., et al. (2016). The Brazilian Zika virus strain causes birth defects in experimental models. Nature, v. 534, n. 7606, p. 267-71, Jun.

Davidson, A., et al. (2016). Suspected Female-to-Male Sexual Transmission of Zika Virus New York City, 2016. MMWR Morb Mortal Wkly Rep, v. 65, n. 28, p. 716-7, JuL.

Deckard, D. T., et al. (2016). Male-to-male sexual transmission of Zika virus - Texas, January 2016. MMWR Morb Mortal Wkly, v. 65, n. 14, p. 372-4, Abr. 
Dick, G. W.; Kitchen, S. F.; Haddow, A. J. (1952). Zika virus. I. Isolations and serological specificity. Trans $R$ Soc Trop Med Hyg, v. 46, n. 5, p. 509-20, Set.

Driggers, R. W., et al. (2016). Zika virus infectionwith prolonged maternal viremia and fetal brainabnormalities. $N$ Engl J Med, v. 374, n. 22, p. 2142-51, Jun.

Duffy, M.R., et al. (2009). Zika virus outbreak on Yap Island, Federated States of Micronesia. N Engl J Med, v. 360, p. 2536-43, Jun.

França, G. V., et al. (2016). Congenital Zika virus syndrome in Brazil: a case series of the first 1501 livebirths with complete investigation. Lancet, v. 388, n. 10047, p. 891-7, Ago.

Frank, C., et al. (2016). Sexual transmission of Zika virus in Germany, April 2016. Euro Surveill, v. 21, n. 23, Jun.

Fréour, T., et al. (2016). Sexual transmission of Zika virus in an entirely asymptomatic couple returning from a Zika epidemic area, France, April 2016. Euro Surveill, v. 21, n. 23, p. $1-3$.

Friedrich, M. J. (2017). WHO Calls Off Global Zika Emergency. JAMA, v. 317, n. 3, p. 246, Jan.

Garza-gonzález E., et al. (2017). Rapid spread of an ongoing outbreak of Zika virus disease in pregnant women in a Mexican hospital. Braz J Infect Dis, pii: S1413-8670, v. 16, p. 30681X, Jun.

Haddow, A. D., et al. (2016). Genetic Characterization of Spondweni and Zika Viruses and Susceptibility of Geographically Distinct Strains of Aedes aegypti, Aedes albopictus and Culex quinquefasciatus (Diptera: Culicidae) to Spondweni Virus. PLoS Negl Trop Dis, v. 10, n. 10, e0005083, Out.

Hills, S. L., et al. (2016). Transmission of Zika virus through sexual contact with travelers to areas of ongoing transmission - Continental United States, 2016. MMWR Morb Mortal Wkly Rep, v. 65, n. 8, p. 215-6, Mar.

Horton, R. (2016). Offline: Brazil-the unexpected opportunity that Zika presents. The Lancet, v. 387, n. 10019, p. 633, Fev.

Marano, G., et al. (2016). Zika virus and the never-ending story of emerging pathogens and transfusion medicine. Blood Transfus, v. 14, n. 2, p. 95-100, Mar.

Martines, R. B., et al. (2016). Notes from the Field: Evidence of Zika virus infection in brain and placental tissues from two congenitally infected newborns and two fetal losses--Brazil, 2015. MMWR Morb Mortal Wkly Rep, v. 65, n. 6, p. 159-60.

Mcgrath, E. L., et al. (2017). differential responses of human fetal brain neural stem cells to Zika virus infection. Stem Cell Reports, v. 8, n. 3, p. 715-27, Mar. 
Meneses, J. D., et al. (2017). Lessons learned at the epicenter of Brazil's congenital Zika epidemic: evidence from 87 confirmed cases. Clin Infect Dis, v. 64, n. 10, p. 1302-8, Maio.

Moura da silva, A. A., et al. (2016). Early growth and neurologic outcomes of infants with probable congenital zika virus syndrome. Emerg Infect Dis, v. 22, n. 11, p. 1953-6, Nov.

Musso, D., et al. (2014). Potential for Zika virus transmission through blood transfusion demonstrated during an outbreak in French Polynesia, November 2013 to February 2014. Euro Surveill, v. 19, n. 15, Abril.

Neta, T. J. C., et al. (2016). Actions developed at the Instituto de Medicina Integral Prof. Fernando Figueira to confront microcephaly by Zika virus. Rev. Bras. Saúde Matern. Infant, v. 16, n. 1, p. 111-6.

Nunes, M. L., et al. (2016). Microcephaly andZika virus: a clinical and epidemiological analysis of thecurrent outbreak in Brazil. J Pediatr (Rio J), v. 92, n. 3, p. 230-40, Jun.

Oliveira, W. K., et al. (2015). Increase in reported prevalence of microcephaly in infants born to women living in areas with confirmed Zika virus transmission during the first trimester of pregnancy - Brazil, 2015. MMWR Morb Mortal Wkly, v. 65, n. 9, p. 242-247, Mar.

Ozkurt, Z.; Tanriverdi, E. C. (2017). Global Alert: Zika Virus-an Emerging Arbovirus. Eurasian J Med, v. 49, p. 142-7, Maio.

Rasmussen, S. A., et al. (2016). Zika virus and birth defects - reviewing the evidence for causality. New Engl J Med, v. 374, n. 20, p. 1981-7, Maio.

Reynolds, M. R., et al. (2017). Vital Signs: Update on Zika Virus-Associated Birth Defects and Evaluation of All U.S. Infants with Congenital Zika Virus Exposure - U.S. Zika Pregnancy Registry, 2016. MMWR Morb Mortal Wkly Rep, v. 66, n. 13, 366-73, Abr.

Saad-roy, C. M.; (2016). Van Den Driessche, P.; MA, J. Estimation of Zika virus prevalence by appearance of microcephaly. BMC Infectious Diseases, v. 16, n. 754, p. 1-6, Dez.

Samarasekera, U., Triunfol, M. (2016). Concern over Zika virus grips the world. The Lancet, v. 387, n. 10018, p. 521-4, Fev.

Sharma, A.; Lal, S. K. (2017). Zika Virus: Transmission, detection, control, and prevention. Front Microbiol, v. 8, p. 110, Fev.

Smith, D. R., et al. (2017). Neuropathogenesis of Zika virus ina highly susceptible immunocompetent mouse model afterantibody blockade of type I interferon. PLoS Negl Trop Dis, v. 11, n. 1, Jan.

The lancet. (2016). Zika virus: a new global threat for 2016. The Lancet, v. 387, n. 10014, p. 96, Jan. 
Vermillion, M. S., et al. (2017). Intrauterine Zika virus infection of pregnant immunocompetent mice models transplacental transmission and adverse perinatal outcomes. Nat Commun, v. 8, p. 14575, Fev.

World Health Organization. (2016). Zika Virus Microcephaly Guillain-Barré Syndrome $\begin{array}{lllll}\text { Situation } & \text { Report. } & 3 & \text { Nov. } & 2016 .\end{array}$ <http://apps.who.int/iris/bitstream/10665/250724/1/zikasitrep3Nov16-eng.pdf>. Access in: 20 jul. 2017.

Yakob, L., Walker, T. (2016). Zika virus outbreak in the Americas: the need for novel mosquito control methods. Lancet Glob Health, v. 4, n. 3, p. 148-9, Mar.

How to cite this article (APA):

Melo, Antonio M. D. de; Neves, Ana B.C.S.; Bernardo, Gabriel P.; Araújo, Ruth F. de; Bernardo, Lorena P.; Parente, Lucas L.T.; Parente, Rodrigo E. L.T.; Telles, Maria V.L. (2017). Zika Virus and Microcephaly: An Enemy of Public Health. Am. In. Mult. J., Oct. 2 (3), 17-25.

Received: 8/2/2017.

Accepted: 8/30/2017. 